\title{
KESULITAN MAHASISWA DALAM PEMBUATAN VIDEO PEMBELAJARAN MENGGUNAKAN MICROSOFT POWERPOINT
}

\author{
${ }^{1}$ Hera Deswita \\ 1'heraiwit18@gmail.com
}

\section{Universitas Pasir Pengaraian}

\begin{abstract}
Video has become one of the main learning tools in distance learning systems. Students as prospective teachers must be able to make quality and interesting videos. One easy-to-use application for creating videos is Microsoft powerpoint. The purpose of this study is to describe the difficulty of students in making learning videos using Microsoft PowerPoint. The research subject is a 5th semester student who took the learning media course on condition that he has passed computer courses I. The research instrument is a questionnaire. Data analysis techniques are qualitatively covering reduction, presenting data, verifying and checking back. Based on the analysis of data it can be concluded that the difficulty of students in making learning videos is that students still have less knowledge in operating Microsoft powerpoint, less creative in designing video displays, low explaining skills and students still have low computer specifications.
\end{abstract}

Keywords: : Student Difficulties, Learning Videos, Microsoft powerpoint

\begin{abstract}
Abstrak: Video pembelajaran sudah menjadi salah satu perangkat pembelajaran utama pada sistem pembelajaran jarak-jauh. Mahasiswa sebagai calon guru harus mampu membuat video yang berkualitas dan menarik. Salah satu aplikasi yang mudah digunakan untuk membuat video adalah Microsoft powerpoint. Tujuan penelitian ini adalah untuk mendeskripsikan kesulitan mahasiswa dalam membuat video pembelajaran dengan menggunakan microsoft powerpoint. Subjek penelitian adalah mahasiswa semester 5 yang mangambil matakuliah media pembelajaran dengan syarat sudah lulus matakuliah komputer I. Instrumen penelitian adalah angket. Teknik analisis data adalah secara kualitatif meliputi reduksi, menyajikan data, memverifikasi dan mengecek kembali. Berdasarkan analisis data dapat disimpulkan bahwa kesulitan mahasiswa dalam pembuatan video pembelajaran adalah mahasiswa masih memiliki pengetahuan yang kurang dalam mengoperasikan microsoft powerpoint, kurang kreatif dalam mendesain tampilan video, keterampitan menjelaskan masih rendah dan Spesifikasi komputer mahasiswa masih rendah.
\end{abstract}

Kata Kunci: Kesulitan Mahasiswa, Video Pembelajaran, Microsoft powerpoint

\section{PENDAHULUAN}

Video pembelajaran sudah menjadi salah satu perangkat pembelajaran utama pada sistem pembelajaran jarak-jauh. Video pembelajaran dapat membantu tugas guru dalam mengajar online. Hal ini karena dalam situasi pandemic siswa harus belajar dari rumah untuk mengurangi laju penularan covid-19. Selain konsep 
pembelajaran harus ditranser dengan optimal, guru sebaiknya tetap mendesain pembelajaran yang menarik dan menyenangkan.

Berbagai aplikasi dapat digunakan untuk membuat video pembelajaran bagi pemula diantaranya camera, Camtasia, kine master, filmora, viva video, powerpoint dan lain sebagainya. Aplikasi tersebut dapat diunduh dengan mudah dan gratis di aplikasi play store. Sedangkan microsoft powerpoint biasanya sudah tersedia otomatis pada komputer/laptop yang terpasang dalam program office

Powerpoint merupakan salah satu aplikasi yang dapat digunakan dengan mudah oleh seorang pembuat video pemula. Langkah-langkah membuat video dengan menggunakan powerpoint sangat mudah. Adapun Langkah-langkah yang dijelaskan Batubara (2016) adalah sebagai berikut

1. Sajikan materi pelajaran pada slide powerpoint sebagaimana membuat presentasi pada umumnya

2. Tambahkan animasi yang sesuai pada objek dan transisi slide sehingga materi pelajaran tampil secara berurutan dan tampak lebih menarik

3. Simpan dokumen PowerPoint dalam format video. Caranya adalah:
a) klik Tab File
b) klik Export
c) klik Create a video

d) klik menu "Presentation Quality" untuk menentukan kualitas video,

e) klik "Record Timing \& Narations" untuk merekam suara presenter dan menentukan durasi waktu berjalannya sebuah slide powerpoint

f) klik "Start Recording" untuk mulai merekam

g) Saat PowerPoint masuk dalam mode Show, silahkan jalankan dan jelaskan isi presentasi Anda dengan sistematis dan tenang

h) setelah selesai menjalankan semua slide, tekan tombol "ESC" untuk mengakhiri pengaturan tampilan PowerPoint dalam hasil rekaman video

i) klik tombol "Create video"

j) Ketik nama video dan tekan tombol "Save".

Dalam perkuliahan media pembelajaran salah satu produk yang dihasilkan adalah video pembelajaran. Jika langkahlanglah tersebut dipraktekkan tentunya ini sangat mudah sekali karena mahasiswa sudah menyelesaiakan matakuliah Komputer I yang salah satu materinya adalah powerpoint. Selain itu mahasiswa juga sering menggunakan powerpoint dalam presentasi tugas di depan kelas. Video pembelajaran yang dihasilkan oleh mahasiswa dapat dijadikan bekal untuk pembelajaran online. Walaupun 
pembelajaran dilakukan secara online namun prinsip-prinsip pedagogik harus tetap dipenuhi dalam pembuatan video pembelajaran. Anwar (2019) menjelaskan ada tujuh aspek yang harus dikuasi guru dalam kompentesi pedagogik yaitu 1 . Menguasai karakteristik peserta didik 2. Menguasai teori belajar dan prinsip-prinsip pembelajaran yang mendidik. 3. Mampu mengembangkan kurikulum 4. Mampu mengembangkan kegiatan pembelajaran yang efektif 5. Mampu mengembangkan potensi peserta didik. 6. Mampu berkomunikasi secara efektif dengan peserta didik 7. Mampu melaksanakan penilaian dan evaluasi. Menurut Patabang (2021) Aspek kompetensi pedagogik yang paling tinggi pada pembelajaran online dimasa pandemi Covid-19 adalah menguasai teori belajar sedangkan aspek yang paling rendah adalah komunikasi dengan peserta didik. Tindak lanjut yang diharapkan adalah agar para guru dalam melaksanakan pembelajaran secara daring lebih mengintensifkan komunikasi baik antara guru dengan peserta didik, maupun komunikasi antarpeserta didik. Untuk menngintensifkan komunikasi dapat dilakukan dengan membuat video pembejaran yang interaktif dan menarik Rancangan video pembelajaran untuk pelajaran matematika harus disesuaikan dengan karakteristik matematika. Salah satu pendekatan yang dapat digunakan adalah konstruktivisme dimana materi yang diajarkan harus secara sistematis agar pengetahuan siswa dapat terkonstruksi dengan baik. Dalam pembuatan video pembelajaran menggunakan microsoft powerpoint, tool yang dapat dimanfaatkan untuk membangun pengetahuan siswa adalah menggunakan animation pane. Dengan menggunakan tool ini materi matematika dapat ditampilkan bertahap setiap langkahnya. Prosedur pemecahan masalah muncul bertahap. Dengan metode seperti ini diharapkan siswa dapat memahami konsep matematika dengan baik. Dengan demikian tujuan dari penelitian ini adalah untuk mendeskripsikan kesulitan mahasiswa dalam membuat video pembelajaran dengan menggunakan microsoft powerpoint.

\section{METODE}

Ini merupakan penelitian deskriptif eksplorati. Menurut Zellatifanny (2018). Penelitian deskriptif merupakan metode penelitian yang berusaha menggambarkan objek atau subyek yang diteliti secara objektif, dan bertujuan menggambarkan fakta secara sistematis dan karakteristik objek serta frekuensi yang diteliti secara tepat. sedangkan Penelitian eksploratori menurut Mudjiyanto (2018) bertujuan memperdalam pengetahuan dan mencari 
ide-ide baru mengenai suatu gejala tertentu, untuk merumuskan masalah secara lebih terperinci atau mengembangkan hipotesis bukan menguji hipotesis. Subjek penelitian ini sebanyak 21 orang mahasiwa semester 5 yang mengambil mata kuliah media pembelajaran dan sudah lulus matakuliah komputer I pada tahun akademik 2019/2020. Instrumen yang digunakan untuk memperoleh data adalah angket terbuka dimana responden bebas mengisi jawaban sesuai kehendaknya (Isnayni, 2020) Ada satu pertanyaan yang diajukan yaitu "Jelaskan kesulitan atau kendala yang kamu hadapai dalam membuat Video Pembelajaran dengan menggunakan Microsoft powerpoint?". Teknik analisis data yang digunakan adalah Teknik deskriptif kualitatif menurut Jana (2018) adalah seleksi data (reduksi), menyajikan data yang diperoleh, serta memverifikasi dan mengecek ulang data dan penarikan kesimpulan

\section{HASIL DAN PEMBAHASAN}

\section{Hasil}

Berdasarkan jawaban yang diberikan responden, hasil reduksi data diperoleh 12 informasi bahwa kesulitan yang dihadapai mahasiswa dalam membuat video pembelajaran dengan menggunakan microsoft powerpoint adalah
1. Proses creating powerpoint ke dalam bentuk video menghabiskan waktu yang lama.

2. Terdapat masalah dalam audio. Jika dalam proses merekam posisi mulut tidak dekat dengan laptop atau tidak memakai earphone maka audio/suara terdengar sangat kecil.

3. Pada saat pembuatan powerpoint mahasiswa kurang kreatif sehingga beberapa kali revisi/perbaikan dalam pembuatannya.

4. Pembuatan rumus/symbol matematika harus dibuat terlebih dahulu ditulis pada microsoft word tetapi setelah dipindahkan ke microsoft powerpoint tampilannya berubah atau menjadi seperti gambar/foto. Hal ini karena mahasiswa yang kurang paham dalam pengoperasiannya.

5. Microsoft powerpoint 2010 kurang baik dalam pembuatan video pembelajaran, suara yang dihasilkan kurang bagus dan sulit dalam memasukkan audio.

6. Perlu beberapa kali merekam video untuk menghasilkan video yang sesuai dengan keinginan.

7. Saat membuat tampilan slide terdapat sedikit kesulitan menentukan background yang baik dan menarik bagi siswa.

8. Versi powerpoint yang terpasang di laptop mahasiswa masih rendah sehingga harus mencari referensi cara 
membuat video dengan menggunakan versi tersebut

9. Kesulitan menggunakan animation pane saat membuat materi agar langkah penjelasan muncul satu per satu.

10. Tidak ada suara yang terekam jika merekam suara langsung dari laptop meskipun sudah pakai microfon. Solusinya adalah merekam layar dari handphone namun kualitas resolusi video nya kurang bagus dan suaranya juga kurang bersih

11. Ketika merekam suara hasilnya selalu terpotong dengan slide berikutnya.

12. Sulit menjelaskan materi pada video karena materi yang ditulis pada slide hanya berisi poin-poin besar saja sehingga proses merekan terjadi berulang-ulaang

\section{Pembahasan}

Dalam proses pembuatan video pembelajaran menggunakn Microsoft powerpoint dibutuhkan pengetahuan dalam mengoperasikan menu dan tool yang terdapat pada aplikasi tersebut. Berdasarkan data yang diperoleh ternyata mahasiswa masih memiliki pengetahuan yang kurang dalam mengoperasikan microsoft powerpoint seperti memanfaatkan animation pane. Kelemahan ini dapat di atasi melalui belajar dengan menonton tutorial yang terdapat di youtube.
Selain itu metode driil dapat diterapkan agar mahasiswa menjadi mahir dalam mengoperasikan powerpoint. Ella (2019) menyatakan bahwa pada metode drill yang menjadi poin keunggulannya adalah pengulangan untuk tujuan memperkuat keterampilan agar permanen. Dengan demikian mahasiswa dapat menngunakan meted ini untuk meningkatkan keterampilannya dalam membuat video pembelajaran

Beberapa tampilan video pembelajaran yang dibuat oleh mahasswa terkesan kurang kreatif. Terlihat ada bebarapa video yang memiliki background dan template yang sama. Setelah ditelusuri ternyata mereka peroleh dari mengunduh dari sumber yang sama. Astuti (2019) mnejelaskan bahwa Kreativitas merupakan kemampuan untuk memikirkan sesuatu dengan cara yang baru dan tidak biasa serta melahirkan solusi yang unik terhadap masalah yang dihadapi. Untuk menciptakan media/ video pembelajaran yang menarik maka mahasiswa harus melatih kreatifitasnya. Hal ini karena peran kreativitas merupakan salah satu keterampilan yang harus dimiliki dalam memasuki abad 21. Segala sesuatu mengalami perubahan yang sangat cepat dan tantangan yang semakin kompleks.

Pembuatan video pembelajaran harus dilengkapi dengan penjelasan terhadap materi yang ditampilkan. Kemampuan 
menjelaskan merupakan salah satu keterampilan dasar mengajar harus dimiliki mahsiswa sebagai calon guru. Namun berdasarkan data angket dan video yang dihasilkan, kemampuan menjelaskan yang dimiliki mahasiswa masih rendah sehingga pembuatan video pada saat merekam suara dilakukan berulang-ulang. Lisnawati (2020) menyatakan bahwa keterampilan menjelaskan sangat penting dimiliki oleh seorang guru karena guru yang terampil dalam menjelaskan akan membuat anak paham dan mengerti tentang apa yang dipelajari. Salah satu strategi agar mahasiswa terlatih dalam menjelaskan materi pelajaran adalah menguasi konsep. Tanpa penguasan materi maka mahasiswa akan kesulitan dalam mentranfer informasi yang terdapat pada materi tersebut. Hal ini dialami oleh mahasiswa yang menyatakan bahwa kendala dalam pembuatan video pembelajaran adalah pada dirinya sendiri yaitu terkadang ada beberapa kata yang salah pada saat penyampaian materi. Selain itu mahasiwa mengalami kesulitan dalam menjelaskan materi pada video karena materi yang ditulis pada slide hanya berisi poin-poin besar saja.

Untuk menghasilkan video yang memiliki kualitas yang baik harus didukung oleh perangkat komputer yang baik pula. Namun berdasarkan hasil wawancara, spesifikasi kompuer/laptop yang digunakan mahasiswa masih rendah sehingga tidak bisa memasang microsoft powerpoint versi tinggi (2016 dan 2019). Akibatnya video yang dihasilkan kurang baik, suara yang dihasilkan kecil, membutuhkan waktu yang lama untuk merender dari bentuk powerpoint ke dalam bentuk video. Untuk melakukan proses rendering dibutuhkan komputer dengan spesifikasi yang tinggi. Semakin tinggi spesifikasi komputer yang digunakan, maka semakin cepat proses rendering yang dilakukan. Dengan demikian maka mahasiswa harus menyediakan perangkat komputer yang memiliki spesifikasi tinggi agar membantu proses pembauatn video pembelajaran yang berkualitas.

\section{SIMPULAN}

Berdasarkan data yang diperoleh maka dapat simpulkan bahwa kesulitan mahasiswa pendidikan matematika dalam pembuatan video pembelajaran menggunakan microsoft powerpoint adalah 1. Mahasiswa masih memiliki pengetahuan yang kurang dalam mengoperasikan microsoft powerpoint seperti memanfaatkan animation pane

2. Mahasiswa masih kurang kreatif dalam menggunakan gambar sebagai background powerpoint agar tampilannya menjadi lebih menarik

3. Kemampuan mahasiswa dalam menjelaskan masih rendah sehingga 
pembuatan video pada saat merekam suara dilakukan berulang-ulang

4. Spesifikasi laptop mahasiswa masih rendah sehingga tidak bisa memasang microsoft powerpoint versi tinggi (2016 dan 2019). Akibatnya video yang dihasilkan kurang baik, suara yang dihasilkan kecil, membutuhkan waktu yang lama dan untuk merender dari bentuk powerpoint ke dalam bentuk video.

\section{DAFTAR RUJUKAN}

Adiwena, B., Hendrawan, A., \& Indrajaya, M. (2021). Perancangan New Media Berbasis Augmented Reality Untuk Mendukung Kegiatan Promosi IKADO Guna Menjangkau Calon Mahasiswa. Artika, 5(1), 41-52.

Anwar, B. (2019). Kompetensi Pedagogik sebagai Agen Pembelajaran. Shaut al Arabiyyah, 6(2), 114-125.

Astuti, R., \& Aziz, T. (2019). Integrasi Pengembangan Kreativitas Anak Usia Dini di TK Kanisius Sorowajan Yogyakarta. Jurnal Obsesi: Jurnal Pendidikan Anak Usia Dini, 3(2), 294-302.

Batubara, H. H., \& Ariani, D. N. (2016). Pemanfaatan video sebagai media pembelajaran Matematika SD/MI. Muallimuna, 2(1), 47-66.

Ela, L. Meningkatkan Keterampilan Membaca Notasi Angka Secara Vokal Dengan Metode Drill Pada Siswa SMP. Jurnal Pendidikan dan Pembelajaran Khatulistiwa, 8(7), 98110.

Isnayni, M. Y., \& Hermansyah, W. (2020). Pengaruh Pembelajaran Sistem Daring Terhadap Mahasiswa Tadris Biologi Dalam Memahami Materi Mata Kuliah Biokimia. ALVEOLI: Jurnal Pendidikan Biologi, 1(1), 22-28.

Jana, P. (2018). Analisis kesalahan mahasiswa dalam menyelesaikan soal matematika pada pokok bahasan vektor. Jurnal Mercumatika: Jurnal Penelitian Matematika Dan Pendidikan Matematika, 2(2), 8-14.

Lisnawati, I., \& Rohita, R. (2020). KETERAMPILAN MENGAJAR PADA GURU TAMAN KANAK-KANAK: TINJAUAN PADA KETERAMPILAN MENJELASKAN. Jurnal Pendidikan, Pengasuhan, Kesehatan dan Gizi Anak Usia Dini (JP2KG AUD), 1(1), 55-70

Mudjiyanto, B. (2018). Tipe Penelitian Eksploratif Komunikasi. Jurnal Studi Komunikasi Dan Media, 22(1), 65-74. 
Jurnal Eksponen, Vol. 11 No. 1, April 2021

Patabang, A., \& Murniarti, E. (2021). Analisis Kompetensi Pedagogik Guru pada Pembelajaran Daring dimasa Pandemi Covid-19. EDUKATIF: JURNAL ILMU PENDIDIKAN, 3(4), 1418-1427.

Zellatifanny, C. M., \& Mudjiyanto, B. (2018). Tipe penelitian deskripsi dalam ilmu komunikasi. Diakom: Jurnal Media Dan Komunikasi, 1(2), 83-90. 